\title{
ON THE SITUATED SOCIO-CULTURAL MEANING OF BENEFACTIVES IN BALINESE
}

\author{
Desak Putu Eka Pratiwi ${ }^{1)}$, I Wayan Arka $^{2)}$, Asako Shiohara ${ }^{3) *}$ \\ STIBA Saraswati Denpasar ${ }^{1}$, Australian National University (ANU)/Udayana University ${ }^{2)}$, \\ Tokyo University of Foreign Studies (TUFS) ${ }^{3)}$ \\ desak.eka.pratiwi@gmail.com ${ }^{1)}$; wayanarka45@gmail.com²); ibashio@gmail.com³
}

\begin{abstract}
Abstrak
Makalah ini memaparkan studi awal tentang benefaktif dalam bahasa Bali yang merupakan analisis berbasis korpus, berdasarkan teori sosio-kognitif tentang makna yang bergantung pada situasi sosial budaya (cf. Langlotz 2015, Danielle \& Evans 2017). Ini merupakan bagian penelitian berbasis korpus yang lebih besar yaitu SCOPIC (Social Cognition Parallax Interview Corpus) yang dapat diakses di http://hdl.handle.net/10125/24742). Konstruksi benefaktif didefinisikan sebagai konstruksi yang menyatakan sebuah tindakan yang dilakukan untuk memberikan keuntungan bagi orang lain (Kittilä \& Zúñiga 2010). Dapat dikatakan bahwa pengertian tentang 'keuntungan bagi orang lain' dalam makna benefaktif bahasa Bali sangat ditentukan oleh budaya masyarakat Bali itu sendiri, yang memiliki makna sosial yang sangat kompleks, di mana konsep seperti 'keuntungan untuk diri sendiri', 'keuntungan timbal balik', 'keuntungan dalam/luar kelompok', dan penghargaan spiritual sangat sentral. Dunia sosial budaya kenyataannya merefleksikan sistem tingkatan bahasa di Bali yang berdasarkan sistem kasta. Terdapat kata-kata yang berbeda dengan makna sosial yang halus, seperti ada tiga kata dalam bahasa Bali yang bermakna 'memberi', di mana pilihan katanya tergantung pada hubungan sosial kekerabatan atau partisipan yang terlibat. Pilihan kata yang salah dapat menyebabkan kesalahan penempatan kedudukan sosial sehingga tidak dapat diterima atau tidak pantas secara sosial, dan tidak menghasilkan makna benefaktif positif yang dimaksud. Temuan awal kami secara mengejutkan menunjukkan bahwa leksikal benefaktif 'memberi', misalnya, 100\% disampaikan dengan menggunakan kata kerja baang, dan ini menunjukkan bahwa korpus SCOPIC bahasa Bali kami cenderung mengarah pada register rendah.
\end{abstract}

Kata kunci: bahasa Bali, benefaktif, korpus linguistik, kognisi sosial, sosiolinguistik

\begin{abstract}
This paper discusses a preliminary corpus-based study of benefactives in Balinese, from a socio-cognitive theory of situated socio-cultural meaning (cf. Langlotz 2015, Danielle and Evans 2017). It is part of larger corpus-based research on parallel texts in the international SCOPIC (Social Cognition Parallax Interview Corpus) project (http://hdl.handle.net/10125/24742). Benefactive constructions are defined as those expressing states of affairs (SoA) that hold to someone's advantage (Kittilä \& Zúñiga 2010). The notion of '(someone's) advantage' in Balinese benefactive meaning is tightly embedded in Balinese cultural worlds, having complex positive social meanings in which concepts such as 'self', 'reciprocity', 'in-.out-group', and spiritual rewards are central. The socio-cultural worlds are evidently reflected in the speech level system in Balinese. There are different forms with fine-grained social meanings such as three words for 'give' in Balinese depending on the relative social relations of event and/or speech participants. An incorrect choice of linguistic device would lead to incorrect
\end{abstract}


social indexing; hence socially unacceptable or inappropriate, not giving rise to the intended positive benefactive meaning. Our findings show that benefactive meaning is expressible through different means (lexical, morphological, and analytical/ constructional). Surprisingly, the lexical benefactive 'give' is $100 \%$ expressed through the verb baang in our Balinese SCOPIC corpus, suggesting that the corpus is rather skewed towards the common (or low) register.

Keywords: Balinese, benefactive, corpus linguistics, social-cognition, sociolinguistics

\section{INTRODUCTION}

Benefactives are constructions used to express that a state of affairs (SoA) hold to someone's advantage. Benefactive constructions conceptually include two human entities, the one who performs an act for someone's benefit (BENEFACTOR) and the one who receives the benefit (BENEFICIARY). Cross-linguistically the same construction may sometimes also serve as a malefactive, whose meanings are generally not a simple mirror image of the benefactive. In addition to proper benefactives which are typically achieved by means of applicatives, specialized case marking and adpositions, benefactive constructions may cover a wide range of related phenomena such as malefactive passives, serial verb constructions and converbal constructions (including e.g. verbs of giving and taking), and other morphosyntactic strategies (Kittilä \& Zúñiga, 2010).

The semantics of benefactives (and malfactives) should be understood as part of more general notion of affectedness in linguistics. Affectedness could be defined as the property of a verb, such that it describes a situation that can be delimited by the direct argument of the verb. Affectedness verbs describe events which are 'measured out' and delimited by their direct arguments (Tenny, 1987:75). If the recipient is positively affected by the action, it is categorized as benefactives, and if the recipient is negatively affected, it is classified as malefactives. There are also cases where the affectedness evaluation is 'neutral'; that is, it is neither positive nor negative. However, as we discuss below, the positive-negative-neutral evaluation is not always straightforward as it involves the understanding of language use and human interaction in a larger socio-cultural context.

We argue that the notion of '(someone's) advantage' in Balinese benefactive meaning is tightly embedded in Balinese cultural worlds, having complex positive social meanings in which concepts such as 'self', 'reciprocity', 'in-group', and 'out-group's are central. Such meanings can be quite subtle, and formally expressed through a combination of linguistic devices: lexical (verbs), morphological (applicative -ang), and phrasal/constructional (PPs/SVCs). The selection of these devices are regulated and constrained by the proper indexing of participant roles (i.e. the actor (A), the recipient/beneficiary (R), and the benefactive entity/service $\mathrm{T}$ (theme)), relative to each other in a given social communicative situation within a complex speech-level system in Balinese. Within such a system, for example, one cannot speak Balinese without knowing the relative social status of speech participants (Arka, 2005:169), and the positive/negative affect that determines the linguistic expressions is dynamically evaluated from one episode to another episode on the basis of the dynamics of the social relations of participants in a given speech event. This is further discussed in the ensuing sections.

The paper is organized as follows. It starts with an overview of Balinese grammar and its socio-cultural context in section 2. Section 3 discusses benefactives in Balinese, which 
covers preliminaries, benefactives coding, applicativization, adposition, serial verb constructions and voice on the verb. Finally, it is closed by conclusion.

\section{BALINESE GRAMMAR AND ITS SOCIO-CULTURAL CONTEXT: AN OVERVIEW}

Balinese typologically shows grammatical relation properties typical for the Indonesian type of Austronesian languages, in terms of voice marking, argument marking, grammatical relation alternations, and other related processes such as relativisation, reflexivisation and control (Clynes, 1995; Artawa, 1994; Arka, 2003a; Pastika, 2006). In a wider typological context, Balinese shows intransitivity split in terms of verbal morphology. Syntactically the overall grammar of Balinese shows a symmetrical alignment system: actor (A) and patient (P) arguments of transitive verbs can be equally selected as the grammatical subject or Pivot without the demotion of the other. In addition to voice morphology (showing Actor Voice (AV), Undergoer Voice (UV), and middle alternations), Balinese also has applicative and causative morphology, which is good evidence that semantic roles and surface grammatical relations are organised as different distinct layers in the grammar.

Grammatical relations (GRs) are surface syntactic relations reflecting particular importance for the workings of the language. Such grammatical importance is typically manifested in relation to the constraints and behaviours in the overall grammatical system. Balinese shows the existence of syntactic Pivot. Pivot's grammatical selectors come from certain exclusive morphosyntactic properties selecting it such as relativisation and control (see Arka, 2013 and Arka, 2016 for details).

In contrast to Pivot, Balinese also shows other argument (sub)classes exhibiting a set of properties: core (or term) and oblique arguments. The argument classification of cores and obliques reflects the syntactic-semantic prominence that plays an important role in Balinese grammar; e.g. in voice/valence alternation, reflexives and applicativisation (Arka, 2016). As we shall see later, these are crucial in the coding of affectedness especially in relation to benefactives in Balinese.

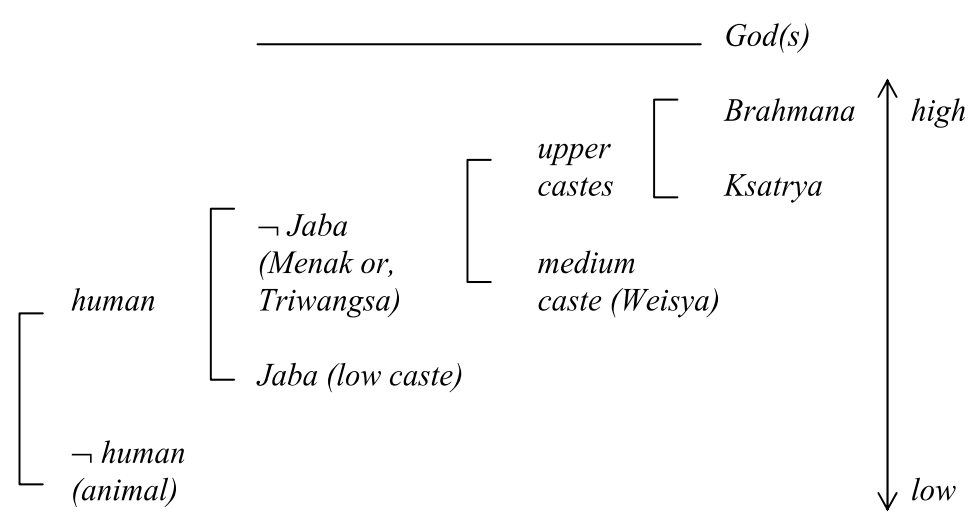

Figure 1. Traditional Social Stratification underpinning Balinese speech-level system

The discussion of benefactives in Balinese should be framed within the broader issues what counts as positive and negative in Balinese social-cultural contexts. This brings us to the grammar and pragmatics of speech levels in Balinese. One cannot speak Balinese without 
knowing the relative social status of speech participants (Arka, 2005:169). While traditionally rooted in the Balinese caste system (shown in Figure 1), the social status underlying the speech level is now also extended to cover modern social stratification based on things like education and jobs in contemporary Bali. Thus, the right high register must be used if the action is for the benefit of a socially superior participant. The high register has its own set of lexical items and morphology, different from the neutral/low register. For example, the verb for 'give' can be expressed in three different ways depending on the actor (A) and recipient (R). First, when the actor and recipient have equal caste level, baang 'give' is used. Second, when the actor has higher caste level, ngicen 'give' is used. Third, when the actor has lower caste level, ngaturang 'give' is used. In terms of morphology, the passive marker for high register is different from the neutral/low register: $k a$ - as in ka-icen 'PASS-give' vs. $-a$ as in baang-a 'give-PASS'.

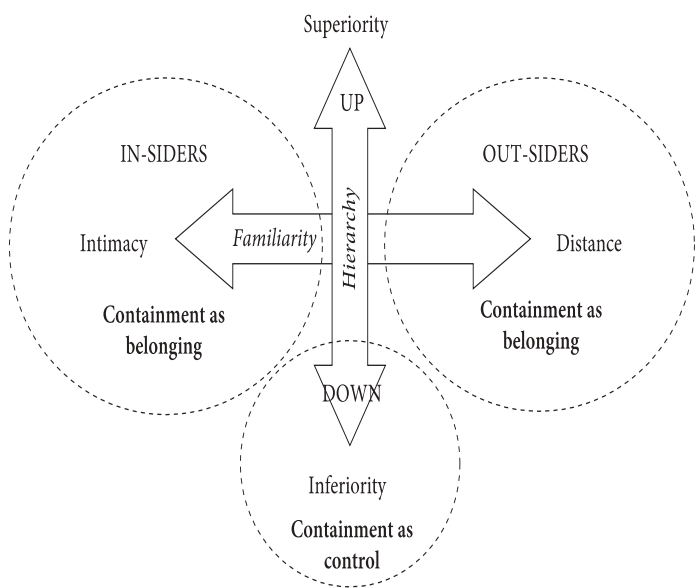

Figure 2. The spatial logic of social order (Langlotz, 2015:26)

An incorrect choice of linguistic devices would lead to incorrect social indexing. It also would result in miscommunication, possibly regarded as offensive and impolite. The high vs. low/neutral register, with its underpinning social stratification shown in Figure 1, is mapped onto the abstract spatial logic of social order, common across languages and cultures, shown in Figure 2 (Langlotz, 2015:26). The point in the mapping is that high register is linked to the social space of superiority in terms of social hierarchy and unfamiliarity in terms of group memberships (i.e. being outsiders). Our discussion on benefative meaning in Balinese is framed within the social space of Balinese worlds, as captured by figures 1 and 2. Thus, an action done for a recipient $(\mathrm{R})$ who is socially superior to the agent $(\mathrm{A})$ is counted as encoding beneficiary only when it is expressed in the correct speech level, which in the case for event of 'giving' the verb aturing/aturang must be used, otherwise it would count as malfactive.

\section{BENEFACTIVES IN BALINESE}

\subsection{Preliminaries}

The term 'benefactive' is a semantic concept, referring to a situation or an event in which someone receives benefit from someone else's action. In typological studies, it is often associated with the benefactive or beneficiary role as part of the semantic role list in the description of semantic argument structure of a predicate; e.g. John has a beneficiary role in both sentences in (1). 
(1)

a. Mary bought a book for John

b. Mary bought John a book

The two sentences in (1) exemplify the benefactive constructions in English ([NPsub V NP.object for NP] and NPsub V NP.ben.obj NP.theme]). They introduce the person (John) that benefits from the action ('buying') expressed by the verb. In short, the beneficiary, John, is a participant that is advantageously affected by an event. The beneficiary role is not necessarily the obligatory participant, as seen in (1a). In this case it is an adjunct which can be left out without affecting the acceptability of the sentence. Furthermore, since normally only animate participants are capable of making use of the benefit bestowed upon them, beneficiaries are typically animate (Kittilä, 2010:15).

Languages differ in terms of the resources available and the ways the benefactive notion is expressed formally. The English examples show the so-called 'dative' alternation in expressing benefative meaning, with (1a) showing the use of the adposition for overtly marking the beneficiary role (1b) making use of the ditransitive structure where the benefative role is the first object.

There are other devices to encode the benefactive event. In what follows, the ones illustrated and discussed are from Balinese, which include serial verb constructions, applicatives, lexical verbs, adpositions, and possibly a combination of these. The data comes from Balinese SCOPIC data, supplemented by other data taken from other sources since there are particular benefactive cases which could not be found in our SCOPIC data. We start with clear cases of benefactives as expressed through lexical means (section 3.2), applicativisation (section 3.3), adposition (3.4) and verb serialization (3.5). We also discuss less clear cases where the combination of certain verbal morphology might give rise to lexicalized benefactive meaning the understanding of beneficiary must be understood as part of the larger socio-cultural context in Balinese.

\subsection{Lexically Coded Benefactives}

Benefactive meaning may be coded lexically, not only in verbs but also in nouns. We discussed cases with verbs first. The clearest examples are the benefactive verbs 'give, offer', which as mentioned earlier, have three distinct formally unrelated roots whose argument structures can be schematized with relational social information specifications shown in (2). The first two, baang and icen, are exemplified here. The last one, -atur, is a bound root, which needs additional morphology to make it a free verb: the middle ma-(matur), or the applicative -ang/-in (aturin/aturang). Since it bears applicative morphology, it will be discussed in section 3.6 below.
a. baang 'give $<\mathrm{A}, \mathrm{R}, \mathrm{T}>$ ', where $\mathrm{A}=\mathrm{R}$
b. icen 'give $<\mathrm{A}, \mathrm{R}, \mathrm{T}>$, where $\mathrm{A}>\mathrm{R}$
c. - atur 'give $<\mathrm{A},(\mathrm{R}),(\mathrm{T})>$ ', where $\mathrm{A}<\mathrm{R}$

The use of baang is attested in SCOPIC corpus exemplified in (3). We have a couple of notes here. First, the verb receives double AV marking, the homorganic nasal $m$ - (due to the bilabial place of articulation) and also the velar nasal $n g(e)$-, apparently in Balinese the AV form maang has been re-analysed as the root rather than the real root baang. 
$\begin{array}{lllllll}\text { (3) } & \text { Polisi-ne } & \text { ngemaang } & \text { ane muani nenenan baju, celana, sandal } \\ \text { police-DEF } & \text { AV.give } & \text { REL male this } & \text { shirt trousers sandal }\end{array}$

'The policeman gave the man t-shirt, pants, sandals'

(Source: SocCog-ban-gianyar2-task_2)

Second, the A and R arguments in (3) are 'the policeman' and 'the man' respectively. The use of the verb ngemaang suggests that modern occupation such as 'police' is socially considered to be 'neutral' in the social stratification in Balinese (cf. Figure 1). Note that from the context in the picture task, we know that this is a description of picture 2 where the policemen and the man are very unlikely to know each other well, and that the speaker considers their social relations equal.

Consider the following excerpt in (4), non-SCOPIC data quoted from a Balinese classical play. This sentence is a highly polite request by Pageh, a patih (minister), to the king (the addressed with the expression of Palungguh Cokor I Dewa). Both are socially of high status, with the King superior to the patih.

(4) Context: a royal court meeting where all the ministers present except the Chief Minister Pangeran Tangkas.

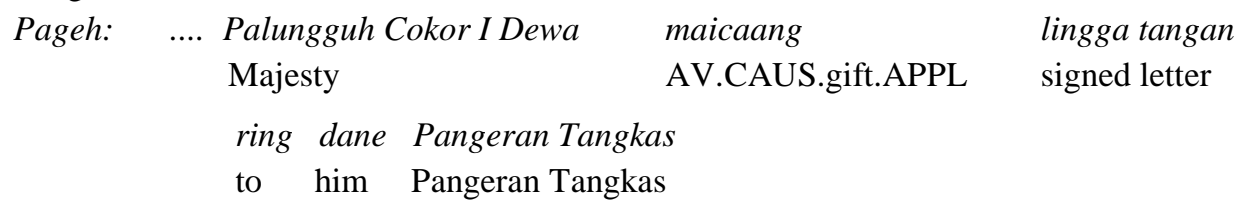

Pageh: '... You just give Prince Tangkas a signed letter.'

(Source: Kasusatran Bali Anyar, page 22)

In terms of semantic roles, the king is the A argument and Pangeran Tangkas, who is the chief minister, is the $\mathrm{R}$ argument. The minister suggested that the king send letter to Pangeran Tangkas. Given that the social status of the chief minister is lower than the king, the word maicaang 'give' is used. This verb is derived from the root ica 'feel pleased', with the causative $p a$ - and the applicative -ang. ${ }^{\mathrm{i}}$ Because the context is a formal royal court, the high register is used.

Certain nouns may also arguably have inherent benefactive meaning in Balinese cultural worlds. For instance, nouns like sesaji/baten 'Balinese offerings to God/spirits' and punjung 'offerings to ancestors' are of this kind, because the offerings are to please the intended $\mathrm{R}$ spiritual beings who are typically socially and culturally superior. The Balinese make offerings dedicated to God and holy spirits. Therefore, the verbs used in relation to sesaji and banten are ngaturang 'give', which is derived from the root atur, instead of baang and icen.

Other examples of nouns with inherent benefactive meaning are tamba 'medicine (high register)' and $u b a d$ 'medicine (low/common register). Tamba is typically associated with a type of medicine given by a socially and culturally superior A. In Balinese there are traditional healers who can heal somebody using spiritual power. Traditional healers are very respected in Bali since they are able to communicate with holly spirits and to heal people. Tamba, being a high register word, is used with the verb icen since the A argument has higher status than the $\mathrm{R}$ argument. While ubad is a common register noun, which requires no such asymmetrical social relation between A and R. It is therefore usable to refer to a common medicine usually given by doctors or by any other ordinary people, and can collocate with the verb baang. In such a case the $\mathrm{A}$ argument is considered having an equal relationship with the $\mathrm{R}$ argument. 


\title{
3.3 Applicativization
}

Beneficiaries are often introduced via applicative constructions. Applicativisation is typically a valency increasing operation. There are two applicative suffixes in Balinese, -ang and -in, and applicative verbs can be derived from various underlying structures. The choice between -ang and -in depends on the applied semantic roles: -ang is for beneficiary, instrumental, and theme whereas $-i n$ is for locative-related (i.e., goal, source and locative) roles. Consider examples (5a) and (5b) in the context of bad drinking habit.

$$
\begin{aligned}
& \text { a. Ia nyemak-ang timpal-ne arak } \\
& \mathrm{He} \text { AV.take friend-DEF alcoholic drink }
\end{aligned}
$$

'He took arak for his friend'

(Source: SocCog-ban-gianyar2-task_2)

(6)

\author{
a. Pah Bli Ngah ngabang ia ne \\ Well brother Ngah AV.bring him DEF \\ 'Well brother Ngah brought it (i.e. alcoholic drink) for him'
b. Bli Ngah ngaba ne
Brother Ngah AV.bring DEF
'Bli Ngah brought this.'

In (5a), the verb is jemakang from the root jemak 'take' (4b); both appear in their AV forms. In (5), the non-applicative nyemak 'take' is monotransitive, assigning two core arguments with ia as subject and arak 'Balinese alcoholic drink' as object. In the derived applicative form, nyemakang, the noun timpalne in (5) is the applied (first) object and the underlying theme object arak now becomes the second object. In this sentence the applicative suffix - ang indicates its general benefactive meaning; that is, the referent timpalne 'his friend' is arguably the recipient-beneficiary of the action of 'taking'. Likewise, the verb root ngaba 'AV.bring' in (6) is applicativised as in (6), to become ngabang. The recipient ia can be likewise analysed as having a beneficiary role.

However, from the larger socio-cultural context, the theme arak is an alcoholic drink, a kind of drink that is negatively valued in Balinese culture. Thus, from a situated socio-cultural context, the action of giving somebody an alcoholic drink of the type shown in (5) and (6) might be perceived as giving rise to a malfactive meaning rather than a benefactive meaning.

It is clear that the presence of an applied object with its own socio-cultural meaning can affect the evaluation of the action of an applicative verb whether it is construable as benefactive or malfactive. This highlights the analytical point of the applicative -ang in Balinese. On one analysis, the applicative - ang in Balinese can be analysed as inherently introducing a recipient role, and the positive or negative (or neither) is further determined by larger structural and socio-cultural contexts. The other analysis is that -ang is a beneficiary marker by default and this default function can be overruled by a more specific use or structure such as the case its presence with an object with negative meaning such as arak. However, given the fact that -ang can also introduce other roles such as theme and instrument, it is clear that -ang is multifunctional in Balinese, not solely a benefactive marker. 


\subsection{Adposition}

Balinese has no (morphological) case to mark recipient/benefactive meaning. Instead, it employs prepositional marking that indicates that the referent of an NP is a recipient argument of a verb. The prepositionally marked NP (by sig/sid (low register), ring (high register)) is grammatically an oblique in Balinese. This PP structure in Balinese alternates with the applicative structure discussed earlier. While the dative is probably the case most frequently used cross-linguistically to encode beneficiaries (Zùñiga \& Kittilä, 2010:7), we do not really have an equivalent structure in Balinese, as there is no preposition meaning 'for' in Balinese. We have not processed all of our SCOPIC data at the moment, and so far a prepositional marked recipient has not been recorded in our corpus. We therefore illustrate the point using examples taken from Kesusatraan Bali Anyar Bali, shown in (7).

(7) Utusan saking Gelgel ngaturang linggatangan Ida Dalem ring Guru A messenger from Gelgel AV.give letter King Ida Dalem for father 'A a messenger from Gelgel gave Ida Dalem's letter for you'

(Source: Kesusatraan Bali Anyar Bali, page 71)

(8) Dolog, surate totonan kudu aturang iba ring Paman Krian Tangkas

Dolog letter that should AV.give you to Pangeran Tangkas

'Dolog, that letter should be given to Prince Tangkas'

(Source: Kesusatraan Bali Anyar Bali, page 101)

In (7), the word ngaturang 'give' is ditransitive which assigns two object arguments, with lingga tangan Ida Dalem 'Ida Dalem's letter' as the first object and Guru 'father' as the second object. In (7), the A is utusan saking Gelgel 'messenger from Gelgel' and the R is Guru 'father' who is the recipient-beneficiary of the action of 'giving'. The speaker in (7) is from the medium caste, in which he talked to his respective father, addressed by using the word Guru. Given the addressee is his father, socially superior, the high register preposition ring 'for' is therefore used. In (8), the object surate totonan 'that letter' takes the subject position in the sentence while $i b a$ 'you' takes non-subject position since that letter is the topic of the sentence. Note that Dolog is a servant, socially inferior to the speaker; hence iba is used. The servant was ordered to give a letter to Pangeran Tangkas, the chief minister. In (8), both the A (Dolog) and the speaker are inferior to Pangeran Tangkas, the intended R. Hence, the speaker uses the high register ring 'for'.

\subsection{Serial Verb Constructions}

In many languages that largely lack case morphology (and in some cases also adposition), serial verb constructions are a productive way of expressing benefaction and malefaction. In this case, a speaker will use a word that expresses the benefit/detriment, along with a particular verb that indicates that this is to someone's benefit/detriment. In Balinese, the clearest example of SVC expressing beneficiary is the one with baang as V2. This verb can appear independently as the main verb. Its occurrence as part of SVC is exemplified in (9)-(10). In these constructions, the verb baang 'give' functions as the second verb in the SVC, contributing its own three-place argument structure, with certain arguments (A and P) shared with the first verb. 
(9) Ia nyemak arak baang=a timpal-ne

He AV.take alcoholic drink UV.give=3 friend-DEF

'He took arak (alcoholic drink) for his friend'

(Source: SocCog-ban-badung2-task_1)

(10) Ia ngalap waluh baang $=a$ kuren-ne

He AVpick.up pumpkin UV.give=3 wife-DEF

'He picked some up pumpkins for his wife'

(Source: SocCog-ban-gianyar2-task_1)

(11) Polisi-ne ngabe baju, celana lan sandal baanga ne muani nenenan Police-DEF AV.bring t-shirt pants and sandals AV.give=a REL male this 'The policeman brought t-shirt, pants and sandals for this man'

(Source: SocCog-ban-badung2-task_1)

All of the sentences above basically have the same construction: V1 + V2.baang, with the verb baang always in the UV form. As seen in (9), the first verb assigns two core arguments, ia 'he' and arak 'alcoholic drink'. The verb nyemak 'take' is the major verb, whereas the second verb baang 'give' the minor verb. Since there is no preposition corresponding to the English preposition for, the serial verb construction with baang has a similar function to the preposition. The verb baang assigns three core arguments, ia 'he', timpalne 'his fiend' and arak 'alcoholic drink.' In (9), timpalne 'his friend' is the beneficiary of the action. Note that in the three examples above, the speaker uses low register since the $\mathrm{A}$ and the $\mathrm{R}$ has equally non-high status. In addition, the examples reflect the typical context where the Balinese tend to use low register when talking among friends within their group although their friends come from a higher caste family.

\subsection{Voice on the Verb}

Balinese voice system has been widely discussed in previous studies of Balinese. Voice in general describes the relationship between the action (or state) that the verb expresses and the participants identified by its arguments. Studies on voice have looked at voice systems from different perspectives, formal morphosyntax to semantics, and discourse pragmatics of information structure (Shibatani, 1988; Cole et al., 2008; Arka, 2003b, 2008; Arka \& Manning, 2008; Arka \& Sedeng, 2018; among others). The main voice types in Balinese are Actor Voice (marked by the homorganic prefix $N$-), Undergoer (or Objective) Voice (unmarked or a zero prefix), Passive Voice (marked by the prefix ka-/suffix - $a$ ) and Middle Voice (marked by ma- (-an)).

From a semantic point of view, the main function of voice marking on the verb is to regulate the direction or flow of affectedness, (i) whether the action initiated by A externally extend its affected to a $\mathrm{P}$ (semantic object), or other participant such as $\mathrm{R}$ (recipient/ beneficiary), or (ii) whether it is self-directed to A. The cases of external benefactives in (i) are associated with actor/undergoer voice (with the difference being discourse-pragmatic prominence whether A or P/R being being the Focus/Topic), and the case in (ii) is associated with the middle voice. In a broader socio-cultural context, the same voice marking could be understood as having multi-directional benefactive meanings.

The clearest examples of the role of voice marking in this respect are voice alternation instances with the same root such as -atur 'say', which may be associated with different directions of the benefactive meaning when it is used with the -ang/-in such as as seen in (12)(14), or with the middle $m(a)--a n$ as in (15). Note that there is no clear benefactive meaning 
arises when the middle is used without -an as in (16). All verbs derived with -atur are in high register because they represent events which require the $\mathrm{R}$ and the addressee that have socially high status, and the A is socially inferior to R.

(12) Putu ngatur-ang banten ring idabatara

Putu AV.say-APPL offering to God

'Putu gave offerings to the almighty God.'

(13) Putu ngatur-in ida batara banten

Putu AV-say-APPL God offering

'Putu gave offerings to the almighty God.'

(14) Putu ngatur-ang banten Nyoman-ne

(external benefactive)

Putu AV.say-APPL offering Nyoman-POS

'Putu dedicated Nyoman's offering to the almighty God.'

(15) Putu m-atur-an

(self-benefactive)

Putu MID-say-AN

'Putu did the offering ritual.'

(16) Putu m-atur

Putu MID-say.

'Putu said/talked (to a superior addressee)'

In (12) and (13), the understood theme object is explicit. The depicted event with the verb atur in these sentences represents an action of doing offering accompanied by some kind of prayers or mantras. The benefactive meaning is external (or non-reflexive) in the sense that the action benefits a participant other than the Actor. Basically both (12) and (13) have the same logical meaning but the constructions are different. The construction in (12) uses the applicative -ang in ngaturang 'give' which assigns two core arguments (Putu and banten 'offering') and one oblique argument (ida batara 'God') with ring as prepositional marking that indicates that the referent of an NP is a recipient argument of the verb. The construction in (13), however, has the applicative suffix -in in verb; ngaturin is a ditransitive construction with two object arguments (ida batara 'God' and banten 'offering'). The recipient ida batara 'God' in (12) is promoted to the first object in (13) in the applicative -in verb, in which case the prepositional marking ring 'to' is no longer needed as seen in (13).

In (14), the verb ngaturang is transitive and assigns one object argument (banten Nyomanne 'Nyoman's offering). The $\mathrm{R}$ does not appear explicitly in this construction. However, in Balinese cultural context it is obvious that the noun banten 'offering' already carries an inherent meaning that it is dedicated to the almighty God. There is no need therefore to express $\mathrm{R}$ role. This sentence also has an external benefactive meaning in the sense that the benefit is for the non-A participant, namely the understood almighty God. However, Nyoman in (14) is the possessor of the offering, and is arguably also understood as the beneficiary of the action since in Balinese cultural context the owner of the offering would benefit from the offering ritual. That is, the A helps Nyoman to dedicate her offering to the almighty God, and in Balinese context, Nyoman would get the spiritual reward of making the offering. The possessive-benefactive connection has been well documented in other languages (Lichtenberk, 2002).

The verb maturan in (15) is derived from the root atur which has the middle voice prefix $m a$ - and the suffix -an, with the understood unexpressed object being banten, and it 
carries the lexical meaning of 'doing an offering ritual for oneself'; i.e. self-benefactive meaning. In this case, the A (Putu) does the action for the benefit nobody else but herself. In Balinese cultural context, the activities in the event of maturan include making offering to the almighty God and also doing the prayers'.

\section{CONCLUSION}

Benefactive meaning in Balinese is arguably generally not a 'simple' or 'primitive' meaning; rather it is as a socio-pragmatically derived complex meaning with 'recipient' being its core meaning. The positive evaluation associated with benefactive meaning is added to this role on the basis of constructional meaning in the larger structural and socio-cultural discourse contexts.

Our preliminary investigation reveals that the core recipient meaning with benefactive implicature in Balinese comes from the verb 'give'. It has been grammaticalised into the benefactive SVC with baang, and the benefactive applicative -ang. However, on the wider socio-cultural perspective, other verbs such as ngayah 'do service' and nouns such as ubad 'medicine' and banten 'offering" (and related derived verbs such as ngubadin 'treat somebody medically' and mantenin/mantenang) also inherently carry benefactive meanings. In actual use, more than one device is possibly employed to express a benefactive meaning.

The voice marking on the verb, however, does not in itself carry a benefactive meaning; rather it regulates the direction of benefit relative to the participants $\mathrm{A}, \mathrm{P}$ or $\mathrm{R}$. The evidence for this comes from voice alternation involving the same root; e.g. actor voice shows externallyoriented benefaction whereas middle voice shows self-directed benefaction.

The preliminary study in this paper is based on a small SCOPIC corpus, which therefore show its limitation; e.g. all instances of the lexical benefactive 'give' are all expressed through the verb baang, suggesting that our Balinese SCOPIC corpus is rather skewed towards the common (or low) register. To illustrate important points, we have supplemented the data using other sources. Future studies are indeed needed to create a large scale of corpus that is representativeness and balanced (McEnery et al., 2006). In addition, further investigation is needed to provide a deeper analysis of the typological position of Balinese among the languages targeted in the SCOPIC project, answering questions such as in what ways Balinese is similar or different from those languages, and beyond.

\section{NOTE}

* We would like to thank an anonymous reviewer for very helpful comments on the earlier draft of this paper.

\section{REFERENCES}

Arka, I W. (2003a). Balinese morphosyntax: A lexical-functional approach. Canberra: Pacific Linguistics.

. (2003b). Voice systems in the Austronesian languages of Nusantara: Typology, symmetricality and undergoer orientation. Linguistik Indonesia 21(1):113-139.

. (2008). Voice and the syntax of $=\mathrm{a} / \mathrm{-a}$ verbs in Balinese. In Voice and grammatical relations in Austronesian languages, P.K. Austin and S. Musgrave (eds.), 70-89. Stanford: CSLI. 
Arka, I W. \& C. Manning. (2008). Voice and grammatical relations in Indonesian: A new perspective. In Voice and grammatical relations in Austronesian Languages, P.K. Austin and S. Musgrave (eds.), 45-69. Stanford: CSLI.

Arka, I W. \& I N. Sedeng. (2018). Information structure in Sembiran Balinese. In A crosslinguistic perspective on information structure in Austronesian languages, S. Riesberg, A. Shiohara and A. Utsumi (eds.). Berlin: Language Science Press.

Artawa, I K. (1994). Ergativity and Balinese syntax. Ph.D. thesis, La Trobe University.

Bresnan, J., A. Asudeh, I. Toivonen, and S. Wechler. (2015). Lexical-Functional Syntax (second edition). Oxford: Wiley-Blackwell.

Clynes, A. (1995). Topics in the phonology and morphosyntax of Balinese. Ph.D. dissertation, Australian National University.

Cole, P.; G. Hermon, \& Yanti. (2008). Voice in Malay/Indonesian. Lingua (118):1500-1553.

Danielle, B. \& N. Evans. (2017). SCOPIC design and overview. In Social Cognition Parallax Interview Corpus (SCOPIC), Language Documentation \& Conservation Special Publication No. 12, D. Barth and N. Evans (eds.). Honolulu: University of Hawai'i Press.

Kittilä, S. \& F. Zúñiga. (2010). Introduction: Benefaction and malefaction from a crosslinguistic perspective. In Benefactives and malefactives: Typological perspectives and case studies, F. Zúñiga and S. Kittilä (eds.), 1-28. Amsterdam: John Benjamins Publishing Company.

Langlotz, A. (2015). Creating social orientation through language: A socio-cognitive theory of situated social meaning. Amsterdam: John Benjamins Publishing Co.

Lichtenberk, F. (2002). The Possessive-benefactive connection. Oceanic Linguistics 41 (2):439474.

McEnery, R.X. \& Y. Tono. (2006). Corpus-based language studies. London: Routledge.

Pastika, I W. (2006). Voice selection in Balinese narrative discourse. Bali-Indonesia: Pustaka Lasaran.

Shibatani, M. (1988). Passive and voice. Amsterdam: John Benjamins.

Williamson, K. (1989). The Niger-Congo overview. In J. Bendor-Samuel, (ed.) The NigerCongo Languages, pp. 3-46. University Press of America, Lanham.

\footnotetext{
${ }^{\mathrm{i}}$ The verb icen appears to be historically verbalisation of the the nominal ice-an 'the thing that the actor does that makes somebody feel pleased.'
} 